\title{
Growth Analysis of Rhizophora Mucronata Mangrove in Ngurah Rai Forest Park (Sanur) Bali Province, Indonesia
}

\author{
Juwari $^{1}$, Daddy Ruhiyat ${ }^{2} \&$ Marlon Ivanhoe Aipassa ${ }^{2}$ \\ ${ }^{1}$ Post Graduate Program of Forestry Faculty Mulawarman University, East Kalimantan, Indonesia \\ ${ }^{2}$ Forestry Faculty of Mulawarman University, East Kalimantan, Indonesia \\ Correspondence: Juwari Achmad, Post Graduate Program of Forestry Faculty Mulawarman University, East \\ Kalimantan, J1. Ki Hajar Dewantara Gedung A6 Kampus Gunung Kelua Samarinda, East Kalimantan, Indonesia. \\ Tel: 628-524-692-3007. E-mail: juwari.achmad@gmail.com
}

Received: December 18, 2019

doi:10.5539/eer.v10n1p30
Accepted: March 20, 2020

Online Published: April 30, 2020

\begin{abstract}
Mangrove forests were a typical type of tropical and subtropical forest, growing along beaches or river mouths that were affected by tides. Mangroves were often found in coastal areas that were protected from the onslaught of waves and sloping areas. Mangrove forest ecosystems had the function of absorbing carbon dioxide (CO2) from the air and storing carbon in the form of biomass. This research was conducted in September 2017. This study aimed to determine the growth, carbon stocks and biomass in mangrove forests in the area of Taman Hutan Raya Ngurah Rai (Sanur) Denpasar. Making research plots used the transect method with a size of 20 meters x 50 meters as many as 3 plots along the coast. From the measurement results, the total value of the base area in plot A was $2.37 \mathrm{~m} 2$ / tree, branch-free volume was $16.57 \mathrm{~m} 3$ / tree, biomass was 13,591 tons / plot, carbon stock was 6,795 tons / plot, the average increment was $0,29 \mathrm{~cm} /$ year / tree. While the results of the measurement of the total value of the base area in plot B was $13.20 \mathrm{~m} 2$ / tree, branch-free volume of $14.87 \mathrm{~m} 3$ / tree, biomass of 8,420 tons / plot, carbon stock of 4,210 tons / plot, average increment amounting to $0.39 \mathrm{~cm} /$ year / tree. Furthermore, the total value of the base area in plot $\mathrm{C}$ was $12.96 \mathrm{~m} 2 /$ tree, branch-free volume was $14.83 \mathrm{~m} 3$ / tree, biomass was 8,265 tons / plot, carbon stock was 4,132 tons / plot, the average increment was $0,40 \mathrm{~cm} /$ year / tree. The salinity value of plot $\mathrm{A}=0.10 \%$ with a $\mathrm{pH}$ of 6.68 , plot $\mathrm{B}=0.09 \%$ with a $\mathrm{pH}$ of 6.78 and plot $\mathrm{C}=$ $0.08 \%$ with a $\mathrm{pH}$ of 6.78 . Based on the calculation results, it could be concluded that the total biomass value of plot $\mathrm{A}=13,592$ tons / plot, plot $\mathrm{B}=14,866$ tons / plot and plot $\mathrm{C}=8,265$ on / plot and then carbon stock plot $\mathrm{A}=$ 6,796 tons / plot, plot $\mathrm{B}=8,420$ tons / plot and plot $\mathrm{C}=4.133$ tons / plot. The average increment per tree obtained values for plot $\mathrm{A}=0.29 \mathrm{~cm} /$ tree / year, plot $\mathrm{B}=0.39 \mathrm{~cm} /$ tree $/$ year and plot $\mathrm{C}=0.40 \mathrm{~cm} /$ tree $/$ year.
\end{abstract}

Keywords: growth, carbon stock, biomass

\section{Introduction}

Mangrove forests were a typical type of tropical and subtropical forest, growing along beaches or river mouths that were affected by tides. Mangroves were often found in coastal areas that were protected from the onslaught of waves and sloping areas. Mangroves grown optimally in coastal areas that had large river mouths and deltas whose waters flow contained a lot of mud. Mangrove reforestation increased marine biota and salt content (Bekti et al., 2017) Mangroves did not or had difficulty growing in steep and choppy coastal areas with strong tidal currents, because these conditions did not allow the deposition of sludge needed as a substrate for its growth. Ghufran \& Kordi, 2012). The degree of acidity $(\mathrm{pH})$ had a great influence on the life of plants/mangroves (Khairul et al., 2018).

The mangrove ecosystem was the main chain that acts as a producer in the coastal ecosystem food nets (Troce et al., 2017). The density of trees decreased from land to sea (Halidah, 2010).

Soil from mangrove forests in terms of habitat and its ecosystem was a mixed environment formed by the meeting between the marine environment and terrestrial environment, which had a major role for human life and for the balance of the ecosystem. Sunlight / lighting greatly influenced growth and flowering (Adhi et al., 2014).

Mangrove forests, like other forests, had a role as absorbers of carbon dioxide (CO2) from the air. Carbon dioxide was closely related to tree biomass. Global warming was the main issue that brings the impact of climate 
change that affects life on earth. Global warming occured due to an increase in the concentration of greenhouse gases (gases) in the earth's atmosphere. The atmosphere was more receptive than releasing carbon, because of burning fossil fuels, motor vehicles and industrial machinery so that carbon accumulates (IPCC, 2007).

Meanwhile the volume of $\mathrm{CO} 2$ absorption was reduced due to deforestation, changes in land use and development. The accumulation of carbon in the atmosphere caused a greenhouse effect, due to trapping short waves of sunlight, thereby increasing the temperature of the Earth's atmosphere. One of the forest ecosystems that could reduce the effects of greenhouse gases and as a mitigation of climate change was mangrove forests (Komiyama, 2014). Mangroves were an invaluable asset of our biodiversity with significant ecological and economic significance (Hema \& Indira, 2015). Ecosystem services traded on the market contributed to human well-being but their economic value was unknown and research was needed to uncover it (Eugene, 2016). Mangrove swamps provided food and shelter for various terrestrial and aquatic organisms (Ekka \& Arun, 2012). Considering the importance of the presence of mangrove then it was necessary to had a service approach to increase how important the existence of mangrove ecosystems (Nibedita et al., 2014).

\section{Method}

\subsection{Location and Time}

This research was conducted in the Sanur Beach Mangrove Forest located in the area of the Grand Forest Park in the City of Kuta, Bali Province, Indonesia. The research was conducted in September 2017.

\subsection{Research Procedures}

Adjusted with the aims and objectives of the study, this research activity consisted of: (a). Making transect lines from the coast to land for the determination of Mangrove forest zoning; (b). Making measurement plots along the transect line; (c). Measurement of tree diameter and height in measurement plots; (d). Testing of edaphic (physical / chemical soil) properties in measurement plots.

\section{a. Making plots along the transect line}

Making research plots using the transect method with a size of 20 meters x 50 meters as many as 3 plots along the coast.

\section{$b$. Measurement of tree diameter and volume}

Measurements were made based on commonly used criteria, namely the diameter of the trunk of the tree at breast height $(130 \mathrm{~cm})$ or limited to the roots at the top of the soil surface.

\section{c. Basal Area Calculation}

Conversion of the diameter obtained by measuring the diameter could be done using the formula:

$$
\text { Basal Area }=1 / 4 \pi \mathrm{d}^{2}
$$

Note. $\pi$ : 3.141592654, d: Tree diameter at breast height.

\section{d. Volume calculation}

Tree volume was measured using the following Ruchaemi (2006) formula:

$$
\mathrm{V}=1 / 4 \pi \mathrm{d}^{2} \times \mathrm{h} \times \mathrm{f}
$$

Note. V: Tree volume (m3), $\pi$ : 3.141592654, d: Tree diameter at breast height, h: Tree height (m), f: Tree shape factor

\section{Results}

\subsection{Measurement of Tree Dimensions}

Rehabilitation or planted forests were planted in 1995 with a spacing of 1 meter x 1 meter, the area planted was 0.435 hectares with the type of mangrove / cape in the local language while the Latin name was Rhizophora mukronata. Mangrove R. mucronata had a high tolerance for its environment (Edi, 2009). To find out the growth and carbon content, measurements were taken with the results like a table 1,2 and 3. 


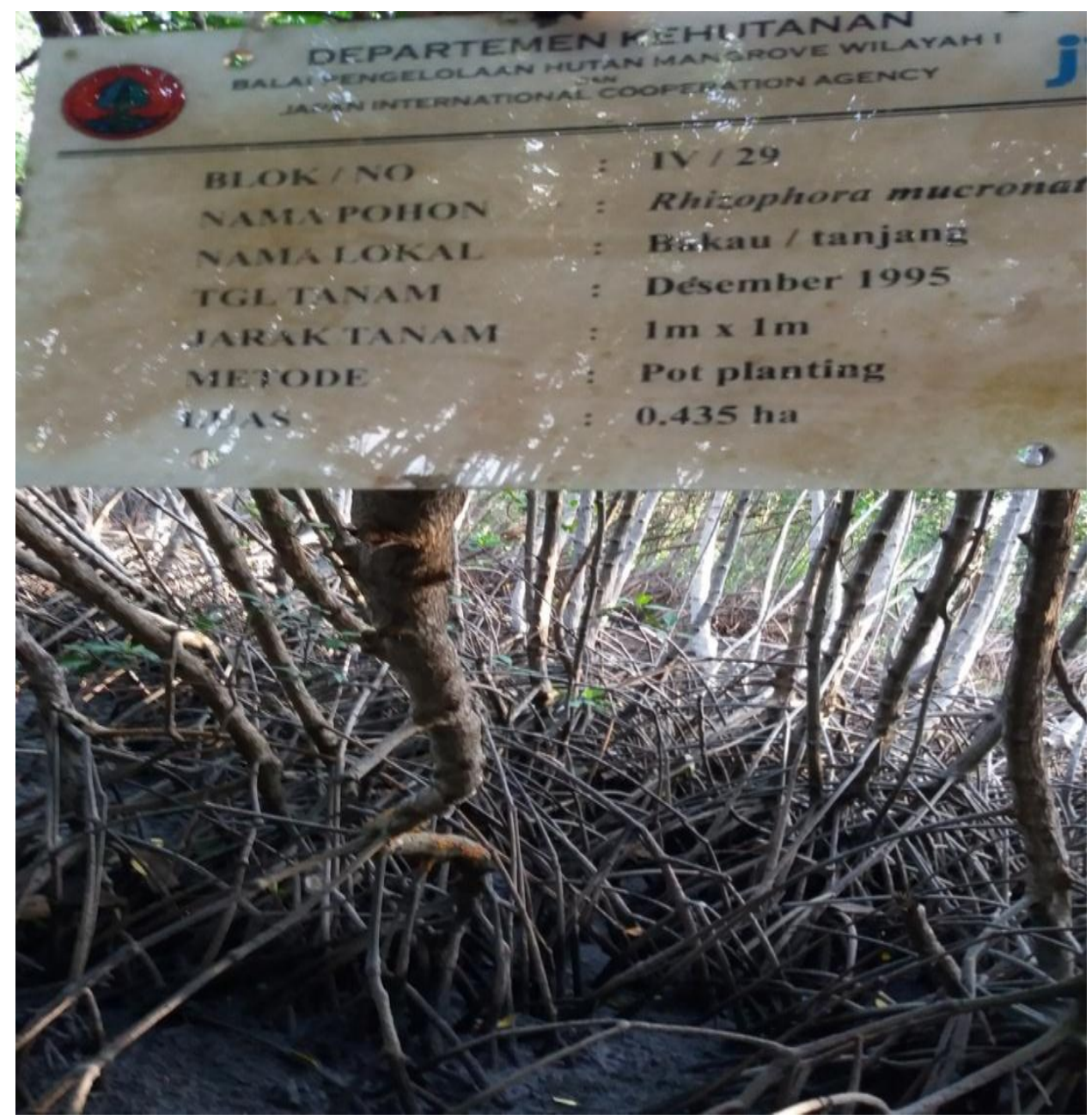

Figure 1. Photo Signboard / signpost for mangrove planting

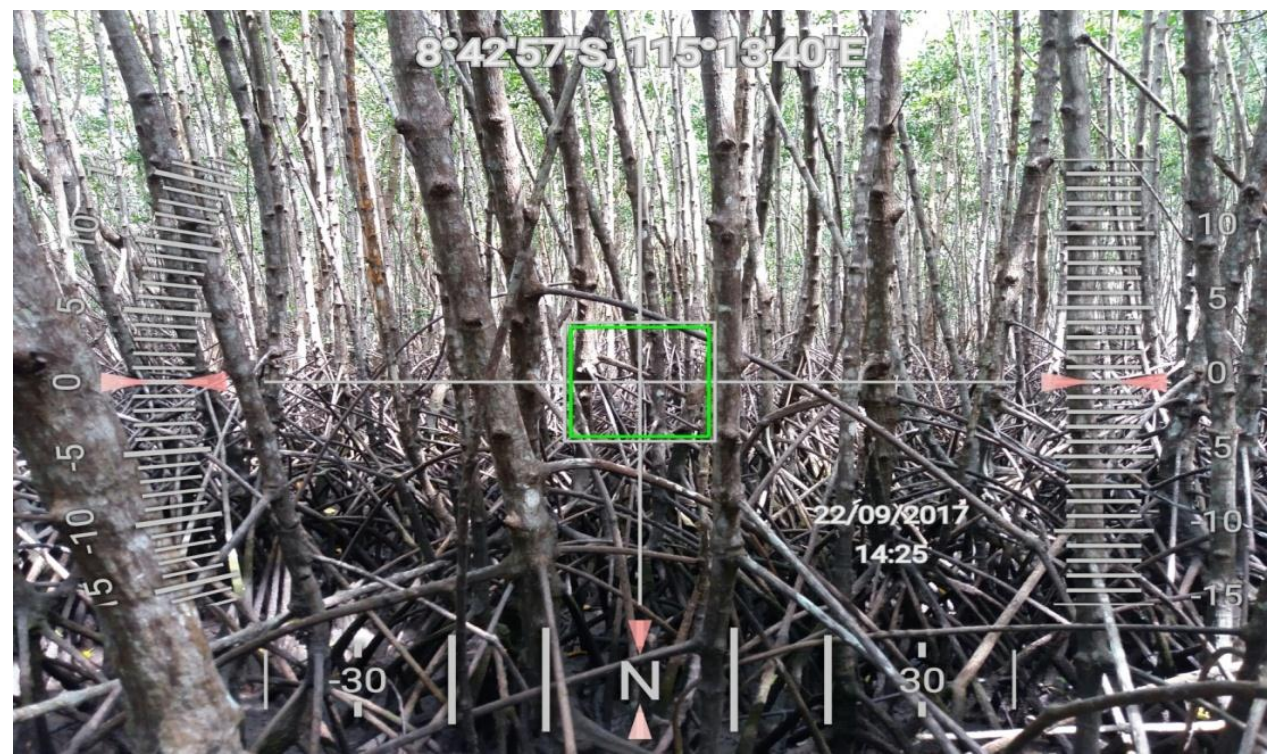

Figure 2. Image of Rhizopora mucronata plant and coordinates in plot A aged 21 years. 
Table 1. Data from Plot A measurement dimensions of Rhizopora mucronata

\begin{tabular}{lccccc}
\hline & V. Total $\left(\mathrm{m}^{3}\right) /$ plot & Biomassa (ton)/plot & Carbon (ton)/plot & Increment/21 years $(\mathrm{cm})$ & Increment/tree/year $(\mathrm{cm})$ \\
\hline Amount & 19.28 & 13.592 & 6.796 & 3.780 & 179.98 \\
Mean & 0.03 & 22.10 & 11.05 & 6.15 & 0.29 \\
\hline
\end{tabular}

Measurement of tree dimensions was carried out in September 2017, from the results of measurements on plot A with a plot size of 20 meters wide and 50 meters long there were as many as 615 trees with a basal area value of $2.37 \mathrm{~m} 2$ / year, total volume value of $19.28 \mathrm{~m} 3$ / year, the value of biomass was 13,592 tons / ha, carbon was 6,796 tons / ha, the average increment value was $0,29 \mathrm{~cm} /$ year / tree.

Table 2. Data on Plot B measurement results of Rhizopora mucronata Dimensions.

\begin{tabular}{lccccc}
\hline & V. Total $\left(\mathrm{m}^{3}\right) /$ plot & Biomassa (ton)/plot & Carbon (ton)/plot & Increment/21 years $(\mathrm{cm})$ & Increment/tree/year $(\mathrm{cm})$ \\
\hline Amount & 14.866 & 8,420 & 4,210 & 3,101 & 147.66 \\
Mean & 0.039 & 22.100 & 11.050 & 8.14 & 0.39 \\
\hline
\end{tabular}

In plot B Rhizophora mukronata as many as 381 trees with a base area value of 13,466 m2 / year, total volume value of $14,866 \mathrm{~m} 3$ / year, biomass value of 8,420 tons / ha, carbon of 4.210 tons / ha, average increment value of $0.39 \mathrm{~cm} /$ year / tree.

Table 3. Data on Plot C measurement results of the Rhizopora mucronata Rehabilitation Forest Dimension.

\begin{tabular}{lccccc}
\hline & V. Total $\left(\mathrm{m}^{3}\right) /$ plot & Biomassa (ton)/plot & Carbon (ton)/plot & Increment/21 years $(\mathrm{cm})$ & Increment/tree/year $(\mathrm{cm})$ \\
\hline Amount & 14.826 & 8,265 & 4,133 & 3,104 & 147.83 \\
Mean & 0.040 & 22.100 & 11.050 & 8.30 & 0.40 \\
\hline
\end{tabular}

\section{Discussion}

In plot C there were 374 trees with a baseline area value of 12,954 $\mathrm{m} 2$ / year, total volume value of 14,286 m3 / year, biomass value of 8,265 tons / ha, carbon of 4,134 tons / ha, average increment value of $0.40 \mathrm{~cm} /$ year /tree.

The increment obtained was still lower compared to the results of the study (Robbi et al., 2016). While carbon and biomass stocks from the results of the three plots above were higher when compared to the results (Andin et al., 2017). R. mucronata type biomass was quite high at 217.22 tons / ha, N.H.Heriyanto and E. Subiandono. 2012. Total biomass ranges from 878,828 grams to 44,226 per pixel and carbon content per pixel ranges from $417,443 \mathrm{gm}$ to $21,008 \mathrm{gmm}$ (Bindu et al., 2018). The value of tree biomass was directly proportional to its carbon value, where the higher the value of biomass, the higher the carbon value. This was because the carbon content value of an organic material was $47 \%$ of the total biomass (National Standardization Agency, 2011) in Edy Handoko, et al. 2016.

Of the three plots above the carbon, stock value was still below the value obtained in mangrove forests 203.83 tons / ha in the village of Bahowo kelahanahan Tongkaina District Bunaken (Fihri et al., 2018). When compared with the results of M. Syukri, et al. 2018 ranging from 1,977 tons / ha was also still higher. Based on the results of the calculation increment shown a very real difference, whereas increasingly towards the sea (from land to sea) increment value was increasing. If we look at the number of trees where the further the sea the number of trees decreases This was one of the factors in the difference in increment value, the more rare the presence of trees, the more competition for nutrition and sunlight. The less competition for nutrition and sunlight, the faster the increment.

As for increasing carbon and biomass stock, the number of trees / density was very influential, where the denser and healthier the number of trees will also increase the amount of carbon and biomass stock. This was consistent with previous research conducted by (Bismark et al., 2008), where the denser and better the condition of mangrove forests, the more carbon was stored.

Based on the calculation results, it could be concluded that the total biomass value of plot $A=13,592$ tons / plot, plot $\mathrm{B}=14,866$ tons / plot and plot $\mathrm{C}=8,265$ on / plot and then carbon stock plot $\mathrm{A}=6,796$ tons / plot, plot $\mathrm{B}=$ 8,420 tons / plot and plot $\mathrm{C}=4.133$ tons / plot. The average increment per tree obtained values for plot $\mathrm{A}=0.29$ $\mathrm{cm} /$ tree $/$ year, plot $\mathrm{B}=0.39 \mathrm{~cm} /$ tree $/$ year and plot $\mathrm{C}=0.40 \mathrm{~cm} /$ tree $/$ year. 


\section{Acknowledgments}

The author would like to thanks for the Ministry of Higher Education and Technology Research for financial support of the author study in Forestry Faculty, Mulawarman University. We would also like to share the gratitude to Daddy Ruhiyat, Marlon Ivanhoe Aipassa who supervised the manuscript and assisted in conducting the study or critiquing the manuscript. The authors thanks to Budi Setiawan for manuscript preparation and the anonymous reviewer for constructive feedback.

\section{References}

Adhi, A., Zikri, A., \& Legowo, K. (2014). Study of mangrove growth in mangrove forest rehabilitation activities in Tanjung Limau Village, Muara Badak District, Kutai Kertanegara Regency. Agrifor Journal, XIII(1).

Andin, I., Nana, K. T. M., \& Satya, B. N. (2017). Estimation of mangrove carbon stocks in Dukuh Tapak, Tugurejo Village, Semarang City. Saintekno, 15(2).

Anjene, E., \& Arun, P. (2012). Willingness to pay for restoration of the natural ecosystem: A study of Sundanese mangroves by contingent valuation approach. Indian Journal of Agruculturel Economics.

Armin, N., \& Wardah, Y. (2014). Soil Chemical Properties in Zoning of Mangrove Forests in Tumpapa Village, Balinggi District, Parigi Moutong District. Wana Rimba Forestry Research Journal, 2(1).

Bekti, U., Sri, B., \& Chatarina, M. (2017). Mangrove forest management strategy in Tanggul Tlare Village, Kedung Subdistrict, Jepara Regency. Journal of Environmental Science, 15(2).

Bindu, G., Poornima, R., Jishnu, E. S., \& Ajith, J. (2018). Carbon stock assessment of mangroves using remote sensing and geographic information systems. The Egyptian Journal of Remote Sensing and Soace Sciences.

Bismark, M., Soebiandono, E., \& Heriyanto, N. M. (2008). Diversity and potential species and carbon content of mangrove forests in the river Subelen, Siberut, West Sumatra. Journal of Forest Research and Nature Conservation, 5(3), 297-306. https://doi.org/10.20886/jphka.2008.5.3.297-306

Candra, S., Andry, I., \& Agus, P. (2012). Growth of Rhizophora mucronata on mangrove restoration land in the Angke Kapuk Protection Forest, Jakarta. Bonorowo Weded, 2(1), 1-10. https://doi.org/10.13057/bonorowo/w020101

Edi, W. K. (2009). Several aspects of bio-physical chemistry of the soil in the mangrove area of Pasar Banggi Village, Rembang Regency. Journal of Marine Sciences, 14(2), 76-83.

Edy, H., Bintal, A., \& Sofyan, H. S. (2016). Analysis of biomass and carbon stocks in mangrove ecosystems in the South Region of Rupat Island. Riau Province. Department of Marine Science, Faculty of Fisheries and Marine Sciences Universitas Riau, Pekanbaru.

Eugene, E. (2016). Willingness to pay for maintenance of a nature conservation area: A case of mount Wilhelm, Papua New Guinea. Asian Social Science, 12(9). https://doi.org/10.5539/ass.v12n9p149

Fahri, B., Calvyn, F. A., Sondakh, \& Janny, D. K. (2018). Estimated carbon uptake of mangrove forests in Bahowo, Tongkaina Village, Bunaken District. North Sulawesi. Journal of Coastal and Tropical Seas, 1(1).

Ghufran, H., \& Kordi, K. (2012). Mangrove Ecosystem. Potential, Function and Management. PT. Rineka Cipta. Jakarta.

Halidah. (2010). The Growth of Rhizophora mucronata Lamk on various substrate conditions in the mangrove rehabilitation area of East Sinjai, South Sulawesi. Journal of Forest Research and Nature Conservation, 7(4), 399-412. https://doi.org/10.20886/jphka.2010.7.4.399-412

Heriyanto, N. H., \& Subiandono, E. (2012). Composition and structure of stands, biomass and potential carbon content of mangrove forests in Alas Purwo National Park. Journal of Forest Research and Nature Conservation, 9(1), 023-032. https://doi.org/10.20886/jphka.2012.9.1.023-032

Heru, S. (2013). Ecological status of mangrove forests at various thickness levels. Walacce Research Journal, 2(2), 104-120.

IPPC. (2007). The Fourth Assessment Report Climate Change. In R. K. Pachauri, \& A. Rasinger (Eds.), IPPC.

Khairul, A., Muclizar, \& Asep, M. (2018). Monthly variations in salinity, $\mathrm{pH}$ and dissolved oxygen in Bengkalis Estuary Waters. Globe Scientific Magazine, 20(2), 58-67. https://doi.org/10.24895/MIG.2018.20-2.645

Komiyama, A. (2014). Conservation of mangrove ecosystems Trough the Eyes of A production ecologist. Agricultural Science, 2, 11-20. https://doi.org/10.7831/ras.2.11 
Muhammad, S., Supriadi, M., Shinta, W., .. \&, \& Solaiman, G. (2018). Study of mangrove carbon stocks in Bebangan, Mamuju Regency, West Sulawesi. Proceedings of the National Symposium on Maritime Affairs and Fisheries.

Nibedita, M., William, J. S., Lynn, D., Jean, H., \& Nico, K. (2014). Ecosystem service valuations of mangrove ecosystems to inform decision making and future valuation exercises. PLOS ONE, 9(9), e107706. https://doi.org/10.1371/journal.pone.0107706

Robbi, A. K., Aishing, K., \& Rudi, H. (2016). Growth in diameter diameter of mangrove ringworm (Rhizophora mucronata) in Lampung Mangrove Center. Silva Lestari Journal, 4(3), 97-106. https://doi.org/10.23960/js13497-106

Troce, M., Hemi, E., Simbala, I., \& Roni, K. (2017). Mangrove biodiversity in Mansuar Island Raja Ampat Regency, West Papua Province. Journal of Bioslogos, 7(2).

\section{Copyrights}

Copyright for this article is retained by the author(s), with first publication rights granted to the journal.

This is an open-access article distributed under the terms and conditions of the Creative Commons Attribution license (http://creativecommons.org/licenses/by/4.0/). 